\title{
Evaluation of Insecticides for Protecting Arizona Cypress (Cupressus arizonica) and One-Seed Juniper (Juniperus monosperma) from Attack by Phloeosinus Bark Beetles
}

\author{
Tom DeGomez, Christopher J. Hayes, John A. Anhold, Joel D. McMillin, and Karen M. Clancy
}

\begin{abstract}
We evaluated the effectiveness of carbaryl, bifenthrin, and permethrin in protecting Arizona cypress (Cupressus arizonica) and one-seed juniper (Juniperus monosperma) from attack by two bark beetles (Phloeosinus spp.). Spray formulations of $2.0 \%$ carbaryl (Sevin SL ${ }^{\circledR}$ ), $0.03 \%$ and $0.06 \%$ bifenthrin $\left(\mathrm{Onyx}^{\circledR}\right.$ ), and $0.19 \%$ permethrin (Permethrin Plus $\mathrm{C}^{\circledR}$ ) were assessed on bolts (sections of logs) of Arizona cypress for their effectiveness in preventing Phloeosinus cristatus attack and colonization. P. cristatus broods were produced in all of the Arizona cypress control bolts. Bifenthrin provided $\geq 80 \%$ and $\geq 70 \%$ protection by the $0.06 \%$ and $0.03 \%$ formulations, respectively, whereas $0.19 \%$ permethrin and $2.0 \%$ carbaryl treatments provided $<70 \%$ protection. Insecticide sprays ( $1.0 \%$ carbaryl, $0.03 \%$ and $0.06 \%$ bifenthrin, and $0.19 \%$ permethrin) were tested for prevention of $P$. scopulorum neomexicanus attack and colonization on one-seed juniper bolts. Bark beetle galleries were present in $62.5 \%$ of the one-seed juniper control bolts. Data on the presence versus absence of $P$. scopulorum neomexicanus galleries indicated that the $0.03 \%$ and $0.06 \%$ bifenthrin and $0.19 \%$ permethrin treatments provided $\geq 90 \%$ protection and the $1.0 \%$ carbaryl spray was $\geq 80 \%$ effective at preventing colonization. The $0.06 \%$ bifenthrin formulation provided the best protection against both species of Phloeosinus beetles.
\end{abstract}

Key Words. Arizona cypress; bark beetle; bifenthrin; carbaryl; insecticides; one-seed juniper; P. scopulorum neomexicanus; permethrin; Phloeosinus cristatus; urban forestry.

The phloeophagous bark beetles in the genus Phloeosinus (Coleoptera: Curculionidae, Scolytinae) contains 27 species recorded in north and central America; they primarily infest trees and shrubs of Taxodioideae and Cupressineae (Wood 1982). In central Arizona, U.S., Phloeosinus-induced mortality has been observed in Arizona cypress (Cupressus arizonica), one-seed juniper (Juniperus monosperma), and alligator juniper (J. deppeana). Current high levels of mortality (USDA Forest Service 2005) and the limited range of Arizona cypress are of concern, causing land managers, arborists, homeowners, and others to consider measures to protect mature high-value trees.

Phloeosinus cristatus and P. scopulorum neomexicanus are little-studied species of bark beetles. Wood (1982) gives some information on their description, distribution, and biology. P cristatus is found from California to Arizona, U.S. and Durango, Mexico, using Cupressus arizonica, C. forbseii., $C$. macrocarpa, Juniperus spp., and Thuja spp. as hosts. Young adults of this species feed by tunneling into the pith of small, healthy twigs. After twig feeding, fully mature adults emerge and attack the lower bole and larger branches, where they form their galleries. P. scopulorum neomexicanus is very common in Utah, ranging from south Idaho to Texas, using C. arizonica, J. deppeana, J. monosperma, and J. osteosperma. This species attacks cut or injured limbs and the bole of live trees; however, the twig-feeding habit described previously has not been observed. In general, Phloeosinus is thought to have between one and 1.5 generations per year with attacks occurring in the spring and summer (Furniss and Carolin 1977).

Liquid insecticides (primarily carbaryl-based formulations) have been evaluated for their effectiveness as treatments to prevent infestation and subsequent brood production by Dendroctonus bark beetles in healthy individual high-value conifers in the western United States (Smith et al. 1977; Hall et al. 1982; McCambridge 1982; Shea et al. 1984; Gibson and Bennett 1985; Haverty et al. 1985; Shea and McGregor 1987; Hastings et al. 2001). However, several questions remain concerning the use of preventive sprays for bark beetles. First, differences in the efficacy of preventive treatments among geographic regions and species of bark beetles (reviewed in Hastings et al. 2001) imply that tests of insecticides should be species and regionally specific. Field tests of carbaryl have not been conducted to determine if it is effective 
in preventing successful Phloeosinus attack. In fact, no studies have been published on preventive treatments for any Phloeosinus species. in the southwestern United States. Second, the duration of efficacy for many of these preventive sprays remains untested. In previous studies, Hall et al. (1982) and Hastings et al. (2001) concluded that many of the carbaryl-based products may have residual activity of anywhere from 3 to 27 months. Finally, because there are doubts regarding the reregistration of carbaryl products, new insecticides should be tested (Haverty et al. 1998).

We evaluated several preventive insecticide sprays to address the issues associated with these regional and species differences in insecticide performance (DeGomez et al. 2006). The purpose of this study was to test the efficacy of carbaryl (Sevin SL ${ }^{\circledR}$, Bayer Environmental Science, Montvale, NJ, U.S.) along with two synthetic pyrethroids, bifenthrin $\left(\mathrm{Onyx}^{\circledR},{ }^{\circledR}\right.$ FMC Corporation, Philadelphia, PA, U.S.) and permethrin (Permethrin Plus $\mathrm{C}^{\circledR}$, Univar, Austin, TX, U.S.) in precluding Phloeosinus colonization of one-seed juniper and Arizona cypress.

\section{MATERIALS AND METHODS}

We conducted two experiments in the summer of 2004 to evaluate the efficacy of preventive insecticide treatments for protecting Arizona cypress and one-seed juniper from attack by Phloeosinus bark beetles. We generally followed the guidelines set forth by Shea et al. (1984) and Haverty et al. (1998) for testing insecticides against Dendroctonus bark beetles.

Bolts were used as surrogates for standing live trees because tree baits (i.e., pheromone lures or host tree compounds) for Phloeosinus spp. have not been developed. Also, Phloeosinus beetles are known to be attracted to and colonize fresh slash (Furniss and Carolin 1977), so we reasoned that using bolts would be the best method for successfully conducting a rigorous test of the preventive insecticides.

\section{Arizona Cypress Experiment}

This experiment was conducted approximately $2 \mathrm{~km}(1.2 \mathrm{mi})$ south of Pine, Arizona, on the Tonto National Forest
$\left(\mathrm{N} 34^{\circ} 21.75^{\prime}, \mathrm{W} 111^{\circ} 25.72^{\prime}\right)$ between 1645 and $1707 \mathrm{~m}$ elevation $(5,429$ to $5,633 \mathrm{ft})$ from 14 June to 10 August 2004. The efficacy of four preventive spray formulations was tested: $0.19 \%$ permethrin with cellulose additive (Permethrin Plus $\left.\mathrm{C}^{\circledR}\right), 0.03 \%$ and $0.06 \%$ bifenthrin $\left(\right.$ Onyx $\left.{ }^{\circledR}\right)$, and $2.0 \%$ carbaryl (Sevin SL ${ }^{\circledR}$ ). Bolts $1 \mathrm{~m}(3.3 \mathrm{ft}$ ) in length, with 7 to $20 \mathrm{~cm}$ (2.8 to 8 in) diameters, were cut from freshly felled pole-sized Arizona cypress trees. Bolts were arranged in a randomized block design; each block consisted of four treatment bolts plus one control bolt placed horizontally on the ground with $0.25 \mathrm{~m}(0.83 \mathrm{ft})$ between the bolts and fresh host tree slash surrounding the block. Treatment blocks (24 replicates) were located next to existing roads with $50 \mathrm{~m}(165 \mathrm{ft})$ between blocks. To ensure that a sufficient number of beetles would be present in the vicinity of each block, we selected a stand containing Arizona cypress with epidemic levels of Phloeosinus cristatus. The insecticide sprays were applied to the point of runoff to bolts lying on the ground with an Ortho ${ }^{\circledR}$ (Scotts Company, New York Mills, NY, U.S.) lawn and garden pesticide sprayer. Each insecticide formulation had its own sprayer to prevent cross-contamination. Approximately $200 \mathrm{~mL}$ ( $\approx 6 \mathrm{fl} \mathrm{oz}$ ) of formulated insecticide was used on each bolt. For the formulations of carbaryl, we tested the water for $\mathrm{pH}$ and added vinegar to bring the water to a $\mathrm{pH}$ of 7.0.

Bark beetle attacks, defined as discreet piles of boring dust, were recorded weekly for $\approx 8$ wk until $80 \%$ of the control bolts had sustained attacks (10 August 2004). At this point, all the bolts were moved from the study site to a shaded area behind the Northern Arizona University (NAU) greenhouse (Flagstaff, AZ). Once beetle exit holes were observed, the bolts were completely peeled and the $P$. cristatus galleries present were counted. Nuptual chambers and egg and larval galleries were all counted as a single gallery.

\section{One-Seed Juniper Experiment}

The experiment was conducted on the NAU/Arizona State Land Department Centennial Forest north of Flagstaff, Arizona ( $\left.\mathrm{N} 35^{\circ} 32.77^{\prime}, \mathrm{W} 111^{\circ} 45.52^{\prime}\right)$ at an elevation of 1920 to $1950 \mathrm{~m}(6,336$ to $6,435 \mathrm{ft})$ from 4 April to 20 July 2004. This

Table 1. Efficacy of preventive spray formulations in protecting Arizona cypress bolts from attack by Phloeosinus cristatus bark beetles.

\begin{tabular}{|c|c|c|c|c|c|c|c|c|}
\hline \multirow[b]{2}{*}{ Insecticide } & \multirow[b]{2}{*}{ I } & \multicolumn{4}{|c|}{ No. of Arizona Cypress Bolts } & \multicolumn{3}{|c|}{$\begin{array}{l}P \text { value for rejecting }{ }^{z} \text { binomial test } H_{\mathrm{o}} \text { that } \\
\text { proportion of successes was } \geq \text { to: }\end{array}$} \\
\hline & & Tested & Failures $^{\mathrm{y}}$ & Successes & Percent success & 0.90 & 0.80 & 0.70 \\
\hline Control & - & 23 & 23 & 0 & $0.0 \%$ & $<0.001$ & $<0.001$ & $<0.001$ \\
\hline Bifenthrin & $0.03 \%$ & 24 & 11 & 13 & $54.2 \%$ & $<0.001$ & 0.002 & 0.071 \\
\hline Bifenthrin & $0.06 \%$ & 24 & 8 & 16 & $66.7 \%$ & $<0.001$ & 0.084 & - \\
\hline Permethrin & $0.19 \%$ & 24 & 13 & 11 & $45.8 \%$ & $<0.001$ & $<0.001$ & 0.009 \\
\hline Carbaryl & $2.00 \%$ & 24 & 18 & 6 & $25.0 \%$ & $<0.001$ & $<0.001$ & $<0.001$ \\
\hline
\end{tabular}

${ }^{\mathrm{z}}$ Rejection is more accurately described as "failing to accept the null hypothesis, $\mathrm{H}_{0}$."

${ }^{\mathrm{y}}$ Treatment failure defined as presence of $P$. cristatus galleries in an individual bolt. 
study tested the efficacy of the following four preventive spray formulations: $0.19 \%$ permethrin with cellulose additive (Permethrin Plus $\left.\mathrm{C}^{\circledR}\right), 0.03 \%$ and $0.06 \%$ bifenthrin $\left(\right.$ Onyx ${ }^{\circledR}$ ), and $1.0 \%$ carbaryl (Sevin SL $\left.{ }^{\circledR}\right)$. Bolts $1.25 \mathrm{~m}(4.13 \mathrm{ft}$ ) in length and 7 to $20 \mathrm{~cm}$ ( 2.8 to $8 \mathrm{in}$ ) in diameter were cut from freshly felled pole-sized juniper trees. Bolts were arranged in the same randomized block design previously described for the Arizona Cypress Experiment. The 24 treatment blocks were located next to existing roads with 50 to $100 \mathrm{~m}$ (165 to 330 $\mathrm{ft})$ between blocks. The stand contained evidence of elevated levels of Phloeosinus beetles but not high tree mortality. Beetles were identified as $P$. scopulorum neomexicanus.

Insecticides were applied as in the Arizona Cypress Experiment described previously. Bolts were checked for attacks biweekly for $\approx 15$ weeks through 20 July 2004 . Attacks by $P$. scopulorum neomexicanus had stopped by this time, most likely as a result of excessive phloem desiccation. All the bolts were brought back to the NAU greenhouse at this point for peeling and evaluation of brood production like in the Arizona Cypress Experiment. When the logs were peeled, we discovered that they did not have completely developed $P$. scopulorum neomexicanus galleries. Instead, the galleries were composed of nuptial chambers, egg galleries (including egg notches), and occasional short, undeveloped larval tunnels. Because this was observed throughout all of the bolts, we assumed that successful larval development was precluded as a result of phloem desiccation. Therefore, we counted a fully developed nuptual chamber accompanied by an egg gallery as a successful colonization.

\section{Determination of Insecticide Efficacy}

We assumed that bolts treated with insecticides had sufficient attack pressure if $\geq 60 \%$ of the untreated control bolts had evidence of successful beetle colonization (i.e., Phloeosinus galleries were present) (Shea et al. 1984; Haverty et al. 1998). However, because bolts were used as surrogates for live trees, our measure of failure or success was based on the presence or absence of Phloeosinus galleries (i.e., successful defense $=$ absence of Phloeosinus galleries) rather than the tree being dead or alive at the end of the experiment.

We used one-sample proportion (i.e., binomial) tests (Analytical Software 2000) to determine if each of the insecticide treatments (and the untreated control) provided a protection rate of $\geq 90 \%$ (i.e., $\mathrm{H}_{0}$ : $\mathrm{p}$ [proportion successes] $\geq 0.90, \mathrm{H}_{\mathrm{A}}$ : $P<0.90, \alpha=0.05)$. The data used for the tests were the number of independent trials (i.e., the number of cypress or juniper bolts tested for each treatment), the number of bolts that were successes (i.e., there were no Phloeosinus galleries present), and the probability of success per trial (between 0 and 1). If we failed to accept the null hypothesis, $\mathrm{H}_{0}$, that the protection rate was $\geq 90 \%$ (i.e., the $P$ value for the binomial test was $<0.05$ ), then we conducted another test to decide if the treatment provided a protection rate $\geq 80 \%$. If the $P$ value for the $\geq 80 \%$ protection rate test was also $<0.05$, we conducted one more test to see if the protection rate was $\geq 70 \%$.

We also analyzed data on the number of Phloeosinus galleries present per $1000 \mathrm{~cm}^{2}\left(160 \mathrm{in}^{2}\right)$ of bark surface area on each bolt. First, we used a Kruskal-Wallis analysis of vari-

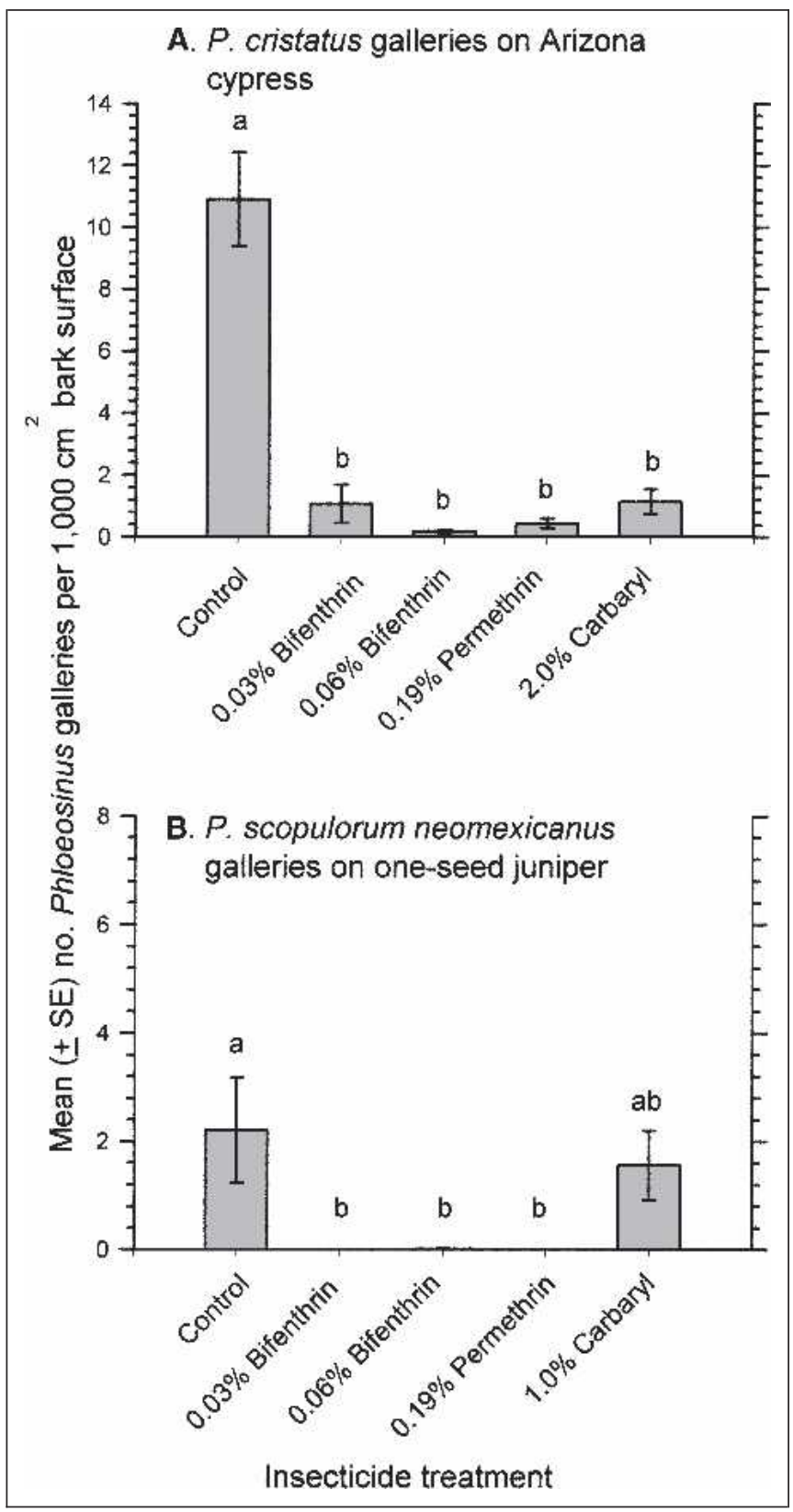

Figure 1. Variation in density of Phloeosinus bark beetle galleries per $1000 \mathrm{~cm}^{2}\left(160 \mathrm{in}^{2}\right)$ of bark surface area per Arizona cypress (A) or one-seed juniper (B) bolt for spray formulations of four insecticide treatments plus an untreated control. Bars with different letters indicate significant differences (analysis of variance on ranks, Dunn's method, $\alpha=0.05$ ). 
ance on ranks to determine if there were differences among the treatments $(\alpha=0.05)$ (Systat Software Inc. 2004). If the overall analysis of variance was significant, we used Dunn's test to conduct pairwise comparisons of all treatment means $(\alpha=0.05)$ (Systat Software Inc. 2004).

\section{RESULTS AND DISCUSSION Arizona Cypress Experiment}

This study exceeded the $60 \%$ criterion for test rigor; $100 \%$ of the control bolts had P. cristatus galleries present (Table 1). None of the insecticide treatments provided $\geq 90 \%$ protection $(P<0.001)$. The $0.06 \%$ bifenthrin treatment had a $\geq 80 \%$ protection rate $(P=0.084)$ and the $0.03 \%$ bifenthrin provided $\geq 70 \%$ protection $(P=0.071)$. The $0.19 \%$ permethrin and the $2.0 \%$ carbaryl treatments had protection rates $<70 \%$ $(P \leq 0.009)$. All the treatments had lower densities of $P$. cristatus galleries compared with the control, but none of the spray treatments differed significantly from each other (Figure 1A). One of the control bolts was most likely removed from the study site by vandals.

\section{One-Seed Juniper Experiment}

In this experiment, $62.5 \%$ of the control bolts had P. scopulorum neomexicanus galleries, thus meeting our $60 \%$ criterion for test rigor (Table 2). The $0.03 \%$ and $0.06 \%$ bifenthrin and the $0.19 \%$ permethrin sprays all provided $\geq 90 \%$ protection $(P \geq 0.691)$, and they had gallery densities lower than the control (Figure 1B). The 1.0\% carbaryl treatment had $\geq 80 \%$ protection $(P=0.161)$, but the gallery density for this treatment did not differ from the control or any of the other treatments (Figure 1B). Identification tags from two of the bolts of the $0.03 \%$ bifenthrin, $0.06 \%$ bifenthrin, and the $0.19 \%$ permethrin and one bolt of the $2.0 \%$ carbaryl were lost during the transport of the bolts from the field to Northern Arizona University greenhouse complex.

The 0.06 and $0.03 \%$ bifenthrin, $0.19 \%$ permethrin, and $2.0 \%$ carbaryl (2.0\% carbaryl only tested against $P$. cristatus) all performed well in terms of bark beetle attack pressure; gallery densities were reduced 10 -fold compared with the controls. It is our opinion that under a natural setting (nonbaited live trees), these insecticide treatments would provide sufficient protection.

The $2.0 \%$ carbaryl formulation tested in the Arizona Cypress Experiment had mixed results. Although it provided $<70 \%$ protection of the bolts (Table 1), it reduced gallery density significantly compared with the control (Figure 1A). The inadequate protection could have been caused by poor bark coverage or penetration by the formulation we used; the bark on the younger wood of Arizona cypress tree boles is smooth and waxy, which may have caused coverage problems. Protection rates might be improved by adding spreaders and stickers to this formulation.

The $1.0 \%$ carbaryl treatment in the one-seed juniper experiment provided $\geq 80 \%$ protection (Table 2 ), but it did not significantly reduce overall gallery density (Figure 1B). These results prevent us from recommending $1.0 \%$ carbaryl sprays for prevention of Phloeosinus spp. attacks.

Questions still remain regarding the duration of the residual activity of these treatments. Two percent carbaryl formulations have been shown to be effective for one to three beetle flight seasons in western bark beetle species (Gibson 1977; Shea et al. 1984; Haverty et al. 1985; Werner et al. 1986). Environmental factors that affect the breakdown of pesticide treatments on the bole of a tree, e.g., sunlight and air temperature, can vary widely from site to site and regionally. DeGomez et al. (2006) reported that the residual activity of $0.06 \%$ and $0.12 \%$ bifenthrin $\left(\mathrm{Onyx}^{\circledR}\right), 2.0 \%$ carbaryl (Sevin $\mathrm{SL}^{\circledR}$ ), and $0.19 \%$ permethrin (Permethrin plus $\mathrm{C}^{\circledR}$ with cellulose additive) sprays applied to ponderosa pine (Pinus ponderosa Dougl ex. Laws.) bolts in northern Arizona was still effective against pine engraver (Ips spp.) beetles 13 months after treatment. A conservative estimate for length of effectiveness for the bifenthrin and permethrin treatments would be one full Phloeosinus beetle flight season, when sprays are applied just before beetle flight in the spring. The residual activity may extend for another year, but we cannot predict the level of protection that might be provided from this experiment.

Table 2. Efficacy of preventive spray formulations in protecting one-seed juniper bolts from attack by Phloeosinus scopulorum neomexicanus bark beetles.

\begin{tabular}{|c|c|c|c|c|c|c|c|c|}
\hline \multirow[b]{2}{*}{ Insecticide } & \multirow{2}{*}{$\begin{array}{l}\text { Percent active } \\
\text { ingredient }\end{array}$} & \multicolumn{4}{|c|}{ No. One-Seed Juniper Bolts } & \multicolumn{3}{|c|}{$\begin{array}{l}P \text { value for rejecting }{ }^{\mathrm{z}} \text { binomial test } \mathrm{p}_{\mathrm{o}} \\
\text { that proportion of successes was } \geq \text { to: }\end{array}$} \\
\hline & & Tested & Failures $^{\mathrm{y}}$ & Successes & Percent success & 0.90 & 0.80 & 0.70 \\
\hline Control & - & 24 & 15 & 9 & $37.5 \%$ & $<0.001$ & $<0.001$ & $<0.001$ \\
\hline Bifenthrin & $0.03 \%$ & 22 & 0 & 22 & $100.0 \%$ & 0.887 & - & - \\
\hline Bifenthrin & $0.06 \%$ & 22 & 1 & 21 & $95.5 \%$ & 0.691 & - & - \\
\hline Permethrin & $0.19 \%$ & 22 & 0 & 22 & $100.0 \%$ & 0.887 & - & - \\
\hline Carbaryl & $1.00 \%$ & 23 & 7 & 16 & $69.6 \%$ & 0.002 & 0.161 & - \\
\hline
\end{tabular}

${ }^{\mathrm{z}}$ Rejection is more accurately described as "failing to accept the null hypothesis, $\mathrm{H}_{0}$."

${ }^{\mathrm{y}}$ Treatment failure defined as presence of $P$. scopulorum neomexicanus galleries in an individual bolt. 
These results may have economic consequences when selecting which insecticide to use given that the base cost of using these insecticides is highly variable. We estimate that $\approx 13 \mathrm{~L}$ (3.4 gal) of mixed insecticide would be used on individual cypress or one-seeded juniper trees. The cost of the insecticide to spray a tree would vary from $\$ 7.00$ (U.S.) for the $2.0 \%$ carbaryl to $\$ 5.40$ for the $0.06 \%$ bifenthrin and $\$ 1.80$ for the $0.19 \%$ permethrin (with cellulose additive). The permethrin was one-fourth the cost of the $2.0 \%$ carbaryl and one-third the cost of the $0.06 \%$ bifenthrin. We assume that other permethrin products without the cellulose additive, labeled for bark beetle control, would have similar efficacy to the Permethrin Plus $\mathrm{C}^{\circledR}$ that we tested for practically the same cost per tree. We caution against using insecticides that are not specifically labeled and formulated for protection against bark beetles because they will be ineffective and economically disappointing.

Acknowledgments. We thank the Northern Arizona University/ Arizona State Land Department Centennial Forest and the U.S. Forest Service for permitting this research on public lands. We are grateful to the following people who assisted during various phases of the project: Brad Blake, Vernon Bunker, T. Seth Davis, Kai DeGomez, Amanda Garcia, Leon Kie, Andrew Miller, Kate Murray, Michelle Shaffer, and Andrew Somerville. This research was supported in part by the Western Bark Beetle Initiative (Participating Agreement 04-PA-11221615-160 between the Rocky Mountain Research Station [K.M.C.] and the University of Arizona [T.E.D.]); Gary Cramer, FMC, Philadelphia, PA; and Christy Davie, Univar, Kirkland, WA. Use or mention of a proprietary product does not constitute an endorsement by the University of Arizona or the U.S. Department of Agriculture Forest Service.

\section{LITERATURE CITED}

Analytical Software. 2000. Statistix 7 User's Manual. Tallahassee, FL.

DeGomez, T.E., C.J. Hayes, J.A. Anhold, J.D. McMillin, K.M. Clancy, and P.P. Bosu. 2006. Evaluation of insecticides for protecting southwestern ponderosa pines from attack by engraver beetles (Coleoptera: Curculionidae, Scolytinae). Journal of Economic Entomology 99: 393-400.

Furniss, R.L., and V.M. Carolin. 1977. Western Forest Insects. United States Department of Agriculture Miscellaneous Publication 1339, Washington, DC.

Gibson, K.E. 1977. Results of a pilot study to test the efficacy of three insecticides in preventing attacks by mountain pine beetle in lodgepole pine. United States Forest Service, Intermountain Regional Office Report 18 pp.

Gibson, K.E., and D.D. Bennett. 1985. Carbaryl prevents attacks on lodgepole pine by the mountain pine beetle. Journal of Forestry 83:109-112.

Hall, R.W., P.J. Shea, and M.I. Haverty. 1982. Effectiveness of carbaryl and chlorpyrifos for protecting ponderosa pine from attack by the western pine beetle (Coleoptera: Scolytidae). Journal of Economic Entomology 75:504-508.

Hastings, F.L., E.H. Holsten, P.J. Shea, and R.A. Werner. 2001. Carbaryl: A review of its use against bark beetles in coniferous forests of North America. Environmental Entomology 30:803-810.

Haverty, M.I., P.J. Shea, and R.W. Hall. 1985. Effective residual life on carbaryl for protecting ponderosa pine from attack by the western pine beetle (Coleoptera: Scolytidae). Journal of Economic Entomology 78:197-199.

Haverty, M.I., P.J. Shea, J.J. Hoffman, J.M. Wenz, and K.E. Gibson. 1998. Effectiveness of esfenvalerate, cyfluthrin, and carbaryl in protecting individual lodgepole pines and ponderosa pines from attack by Dendroctonus spp. Pacific Southwest Research Station Forest Service United States Department of Agriculture Research Paper PSW-RP-237.

McCambridge, W.F. 1982. Field tests of insecticide to protect ponderosa pine from mountain pine beetle (Coleoptera: Scolytidae). Journal of Economic Entomology 75: 1080-1082.

Shea, P.J., and M.D. McGregor. 1987. A new formulation and reduced rates of carbaryl for protecting lodgepole pine from mountain pine beetle attack. Western Journal of Applied Forestry 2:114-116.

Shea, P.J., M.I. Haverty, and R.C. Hall. 1984. Effectiveness of fenitrothion, and permethrin for protecting ponderosa pine trees from attack by the western pine beetle. Journal of the Georgia Entomological Society 19:427-433.

Smith, R.H., G.C. Trostle, and W.F. McCambridge. 1977. Protective spray tests on three species of bark beetle in western United States. Journal of Economic Entomology 70:119-125.

Systat Software, Inc. 2004. SigmaStat 3.1 User's Manual. Systat Software, Inc., Point Richmond, CA.

U.S. Department of Agriculture Forest Service (USDA Forest Service). 2005. Forest insect and disease conditions in the southwestern region, 2004. USDA Forest Service Southwestern Region R3-05-01.

Werner, R.A., F.L. Hastings, E.H. Holsten, and A.S. Jones. 1986. Carbaryl and lindane protect white spruce (Picea glauca) from attack by spruce beetle (Dendroctonus rufipennis) (Coleoptera: Scolytidae) for three growing seasons. Journal of Economic Entomology 79:1121-1124.

Wood, S.L. 1982. The Bark and Ambrosia Beetles of North and Central America (Coleoptera: Scolytidae), a Taxonomic Monograph. Great Basin Naturalist Memoirs No. 6.

Tom DeGomez (corresponding author)

University of Arizona

School of Natural Resources

NAU Box 15018

Flagstaff, AZ 86011-0001, U.S.

degomez@ag.arizona.edu 
Christopher J. Hayes

University of Arizona

School of Natural Resources

NAU Box 15018

Flagstaff, AZ 86011, U.S.

\section{John A. Anhold}

USDA Forest Service

Southwestern Region

Forestry and Forest Health

Arizona Zone

2500 S. Pine Knoll Drive

Flagstaff, AZ 86001, U.S.

Joel D. McMillin

USDA Forest Service

Southwestern Region

Forestry and Forest Health

Arizona Zone

2500 S. Pine Knoll Drive

Flagstaff, AZ 86001, U.S.

\section{Karen M. Clancy}

USDA Forest Service Research and Development

Rocky Mountain Research Station

2500 S. Pine Knoll Drive

Flagstaff, AZ 86001, U.S.

Résumé. Nous avons évalué l'efficacité du carbaryl, du bifenthrin et du permethrin pour la protection du cyprès de l'Arizona (Cupressus arizonica) ainsi que du genévrier à une graine (Juniperus monosperma) contre les attaques par deux scolytes (Phloeosinus spp.). Des formulations de 2,0\% de carbaryl (Sevin SL ${ }^{\circledR}$ ), de $0,03 \%$ et $0,06 \%$ de bifenthrin $\left(\right.$ Onyx $^{\circledR}$ ) et de $0,19 \%$ de permethrin (Permethrin Plus $\mathrm{C}^{\circledR}$ ) ont été vaporisées sur des trous présents dans des sections de tronc de cyprès de l'Arizona afin de tester leur efficacité pour prévenir l'attaque et la colonisation par le Phloeosinus cristatus. Des couvées de $P$. cristatus ont été produites sur toutes les sections de tronc avec des trous chez le cyprès de l'Arizona. Le bifenthrin a donné plus de $80 \%$ et plus de $70 \%$ de protection respectivement avec des concentrations de $0,06 \%$ et $0,03 \%$, tandis que le permethrin à $0,19 \%$ et le carbaryl à 2,0\% ont donné moins de $70 \%$ de protection. Des vaporisations d'insecticides $-1,0 \%$ de carbaryl, $0,03 \%$ de bifenthrin et $0,19 \%$ de permethrin - ont aussi testées pour la prévention contre les attaques et la colonisation par le $P$. scopulorum neomexicanus sur le genévrier à une graine. Des galeries de scolytes étaient présentes sur $62,5 \%$ des sections témoins de tronc de genévrier à une graine. Des données sur la présence de galeries versus l'absence de $P$. scopulorum neomexicanus ont indiqué que les traitements avec du bifenthrin à $0,03 \%$ et à $0,06 \%$ ainsi que du permethrin à $0,19 \%$ donnaient plus de $90 \%$ de protection, et ce alors que le carbaryl à 1,0\% donnait plus de $80 \%$ de protection effective pour prévenir la colonisation. La formulation de bifenthrin à $0,06 \%$ est celle qui donne la meilleure protection contre les deux espèces de Phloeosinus.

Zusammenfassung. Wir bewerteten die Effektivität von Carbaryl, Bifenthrin und Permethrin im Einsatz gegen Borkenkäferbefall bei Cupressus americana und Juniperus monosperma. An einer Auswahl von Zypressenstämmen wurden Sprühlösungen mit 2,0 \% Carbaryl, 0,03\% uns 0,06\% Befenthrin und 0,19\% Permethrin eingesetzt, um einen Befall und Kolonisation mit Phloeosinus cristatus zu verhindern. Die Käferbrut wurde in allen Kontrollstämmen gefunden. Bifenthrin schützte mit $\geq 80 \%$ bei $0,06 \%$ iger Lösung und $\geq 70 \%$ bei $0,03 \%$ iger Lösung, Permethrin und Carbaryl hatten beide eine Effektivität von $<70 \%$. An Wacholderstämmen wurden Insektensprays auf ihre Effektivität gegen Befall und Kolonisation durch P. scopulorum neomexicanus getestet. In 62,5\% der Kontrollstämme fand man Käfergallerien. Die Daten über das Vorkommen bzw. Abwesenheit des Käfers zeigten, dass die 0,03\% und 0,06 $\%$ Bifenthrin, sowie 0,19\% Permethrin $\geq \%$ igen Schutz boten, während $1,0 \%$ Carbaryl zu $\geq 80$ Effektivität zeigten. Die 0,06 \%ige Bifenthrin-Lösung lieferte den besten Schutz gegen beide Käferarten.

Resumen. Se evaluó la efectividad de carbaryl, bifentrín y permetrín para proteger ciprés Arizónica (Cupressus arizonica) y junípero (Juniperus monosperma) del ataque de dos escarabajos de la corteza (Phloeosinus spp.). Se probaron formulaciones en spray al $2.0 \%$ de carbaryl (Sevin SL $\left.{ }^{\circledR}\right), 0.03 \%$ y $0.06 \%$ de bifentrín (Onyx ${ }^{\circledR}$ ), y $0.19 \%$ de permetrín (Permethrin Plus $\mathrm{C}^{\circledR}$ ), en secciones de troncos de ciprés Arizónica para probar su efectividad en la prevención de la colonización y ataque de Phloeosinus cristatus. Los P. cristatus se reprodujeron en todos los trozos de ciprés Arizónica como control. Bifentrín dio un $\geq 80 \%$ y $\geq 70 \%$ de protección por las formulaciones al $0.06 \%$ y $0.03 \%$, respectivamente; mientras que los tratamientos de permetrín al $0.19 \%$ y carbaryl al $2.0 \%$ dieron protección del $<70 \%$. Los spray insecticidas ( $1.0 \%$ carbaryl, $0.03 \%$ y $0.06 \%$ bifentrín, y $0.19 \%$ permetrín) fueron probados para prevención de la colonización y ataque de $P$. scopulorum neomexicanus en un brinzal de juníperus. Las galerías del descortezador estuvieron presentes en $62.5 \%$ de los controles. Los datos de la presencia versus la ausencia de galerías de $P$. scopulorum neomexicanus indicaron que los tratamientos de $0.03 \%$ y $0.06 \%$ de bifentrín y $0.19 \%$ de permetrín dieron $\geq 90 \%$ de protección, y el spray de carbaryl al $1.0 \%$ fue $\geq 80 \%$ efectivo en la prevención de la colonización. La formulación de bifentrín al $0.06 \%$ proporciona la mejor protección contra las dos especies de escarabajos de Phloeosinus. 